\title{
Effects of low-dose morphine suppress methamphetamine- -induced cell death by inhibiting the ROS generation and caspase-3 activity
}

\author{
Amini $\mathrm{K}^{1}$, Zhaleh $\mathrm{H}^{2}$, Tahvilian $\mathrm{R}^{1}$ \\ Pharmaceutical Sciences Research Center, School of Pharmacy, Kermanshah University \\ of Medical Sciences, Kermanshah, Iran. Hossain_jale@yahoo.com
}

\begin{abstract}
OBJECTIVE: Methamphetamine in low doses can increase vigilance and power and at high doses has destructive effects that cause toxicity and death of various cell lines and affect the central nervous system. Morphine has also protective properties, which were observed in low concentrations, for nerve cells and also seem to have the ability to reduce cell death in neural cell lines.

MATERIALS AND METHODS: In this study, we used PC12 and U87 cell lines, which grew in DMEM culture media. Assays used in this study are listed below: MTT test for cell viability detection, LDH test for cytotoxicity measurement, caspase activity colorimetric assay kit (Bio-techne) for caspase 3 activity diagnosis, Rhodamine 123 for Detection of mitochondrial membrane potential. TUNNEL test for DNA fragmentation, fura-2 for Measurement of $\left(\mathrm{Ca}^{2+}\right)$ ic and $\left(\mathrm{Ca}^{2+}\right) \mathrm{m}$. fluorescence microscope for measurement of antioxidant enzyme activities. RESULTS: morphine increased cell viability and the rhodamine-123 absorbance. It reduced cell cytotoxicity, caspase 3 activity, ic \& $\mathrm{m} \mathrm{Ca}{ }^{2+}$ concentration, $(. \mathrm{OH})$ generation, and DNA fragmentation in all concentrations of $1 \mathrm{pM}$ t0 $100 \mathrm{nM}(\mathrm{p}<0.05)$ by optimal concentration of $1 \mathrm{pM}$.

CONCLUSION: morphine as a pain mediator can reduce the methamphetamine-induced cell death, may be due to its anti-inflammatory properties (Fig. 7, Ref. 52). Text in PDF www.elis.sk. KEY WORDS: methamphetamine, morphine, apoptosis, cell death.
\end{abstract}

\section{Introduction}

Over the past decades, methamphetamine use has grown as an opiate in the world, slowly becoming a major global concern and involving 15 to 16 million people since $2007(1,2)$. Methamphetamine is known by the names of glass, crystal, ice, speed, and meth and it can be smoked, snorted, injected, swallowed, or inserted rectally $(3,4)$. Methamphetamine is inexpensive and easy to use, which is why it is rapidly expanding in the world. Methamphetamine secretes nerve mediators such as: dopamine, serotonin and norepinephrine, which leads to a sense of satisfaction, increased consciousness and increased energy in the users. Because of the half-life of 12 hours, these effects remain for many hours, more than cocaine, but long-term use leads to destructive effects on the central nervous system. Respiratory failure, myocardial problems,

${ }^{1}$ Pharmaceutical Sciences Research Center, School of Pharmacy, Kermanshah University of Medical Sciences, Kermanshah, Iran, and ${ }^{2}$ Substance Abuse Prevention Research Center, Kermanshah University of Medical Sciences, Kermanshah, Iran

Address for correspondence: $\mathrm{H}$. Zhaleh, Substance Abuse Prevention Research Center, Kermanshah University of Medical Sciences, 1435944711 Kermanshah, Iran.

Phone/Fax: +98.83.34274545

Acknowledgment: The authors would like to thank the Kermanshah University of Medical Sciences, Iran for the support of this work. cardiomyopathy and increased risk of hepatitis and HIV viruses were observed in long-term amphetamine users (5-10).

Apoptotic genes expression analysis showed that methamphetamine can alter these gene expressions in the way of apoptosis. Furthermore, studies revealed that this drug by networking between mitochondrial, endoplasmic reticulum, and receptormediated apoptosis, can disrupt the striatal enkephalinergic neurons $(11,12)$. Methamphetamine involves in the JNK/SAPK-cJun Pathway, Mitochondrial Cell Death Pathway, Endoplasmic Reticulum (ER)-dependent Death Pathway and FasL/Fas Death Pathway (13-18).

Morphine as a member of the narcotic analgesics family affects the central nervous system and is used to treat pain. Morphine half-life is 1.5-7 hours and its products are available in oral form (tablets and capsules), injectable (intravenous, subcutaneous and muscular) and of course, it can also be inhaled (19-21). There is evidence that morphine in low dose can protect Oxidant-Induced Injuries and cell death in neuronal cell lines of human models by inhibition of glycogen synthase kinase-3 $\beta$ (GSK-3 $\beta$ ). In this regard, many pathways are involved such as: phosphatidylinositol 3-kinase (PI3K), the target of rapamycin (TOR), JAK/STAT and the NO/cGMP/PKG pathway (19, 22-24). On the other hand, morphine was introduced as an antioxidant due to the reduction of the ROS production (25). The inhibitory effects of morphine, in low dosages, at the disruptive effects of 
methamphetamine on nerve cell lines have not yet been tested. Therefore, in this study, we intended to calculate the protective power of morphine on the U87, a human primary glioblastoma cell line (26) and also in the PC12 cell line, derived from a pheochromocytoma in adrenal medulla of the rat treated (27) with methamphetamine simultaneously. U87 is a common cell line that is used in many central nervous system studies. Therefore, we continued our studies on this cell line. On the other hand, methamphetamine causes cell death (28). Due to the opposite effects of methamphetamine and morphine on signaling pathways leading to apoptosis and ROS production, we suggested that by exposing different concentrations of morphine to a constant concentration of methamphetamine in the U87 and PC12 cell lines, we can see the protective effect of morphine on methamphetamine-induced cell death. By measurement of the cell cytotoxicity, cell viability, and apoptotic sings such as: intracellular and extracellular $\mathrm{Ca}^{2+}$ concentrations, we aimed to investigate the correctness of this issue.

\section{Materials and methods}

\section{Cell culture}

DMEM culture media (Gibco) was used for PC12 and U87 cell growth. $10 \%$ fetal bovine serum (FBS, Gibco), $1 \%$ non-essential amino acid (NEAA, Sigma), 2 mM L-glutamine (Sigma), 100 IU/ $\mathrm{ml}$ penicillin (Sigma), and $100 \mu \mathrm{g} / \mathrm{ml}$ streptomycin (Sigma) were used as supplement in T-25 $\mathrm{cm}^{2}$ tissue culture flasks. The cultures were incubated at $37^{\circ} \mathrm{C}$ in $5 \% \mathrm{CO}_{2}$ medium and it was repeated once in two days. In the time of 70 to $80 \%$ confluency, the cell cultures were trypsinated using trypsin-EDTA $0.25 \%$ (Sigma) and were subcultured at a density of $1 \times 10^{4}$ cells/well in 24-well culture plates.

\section{Cell treatment}

The PC12 and U87 cells were washed with PBS in $\mathrm{pH} 7.4$, the day after plating the cells. There were seven treatments for PC12 cells and seven treatments for U87 cells by the same concentration of methamphetamine and morphine, including; control: culture medium, Treatment 1: $1 \mathrm{mM}$ methamphetamine, Treatment 2: $1 \mathrm{mM}$ methamphetamine/1 pM morphine, Treatment 3: $1 \mathrm{mM}$ methamphetamine/10 pM morphine, Treatment 4: $1 \mathrm{mM}$ methamphetamine/100 pM morphine, Treatment 5: $1 \mathrm{mM}$ methamphetamine/1 nM morphine, Treatment 6: $1 \mathrm{mM}$ methamphetamine/10 nM morphine, and Treatment 7: $1 \mathrm{mM}$ methamphetamine $/ 100 \mathrm{nM}$ morphine. Then, the cells were placed in the incubator at $37^{\circ} \mathrm{C}$ with $5 \% \mathrm{CO}_{2}$. The cells were cultured in DMEM culture medium containing $0.2 \% \mathrm{BSA}$.

\section{Cell viability (\%) measurement (MTT assay)}

In this study, the cell viability was quantified by MTT assay. In this regard, $15 \times 10^{3}$ cells were loaded into a 96-well plate and $200 \mu \mathrm{L}$ of DMEM media, which contains $0.2 \%$ BSA was added. After $24 \mathrm{~h}$ incubation, $200 \mu \mathrm{L}$ of each treatment media was added to the wells. The cells were separately incubated with different treatment media for 24 hours.
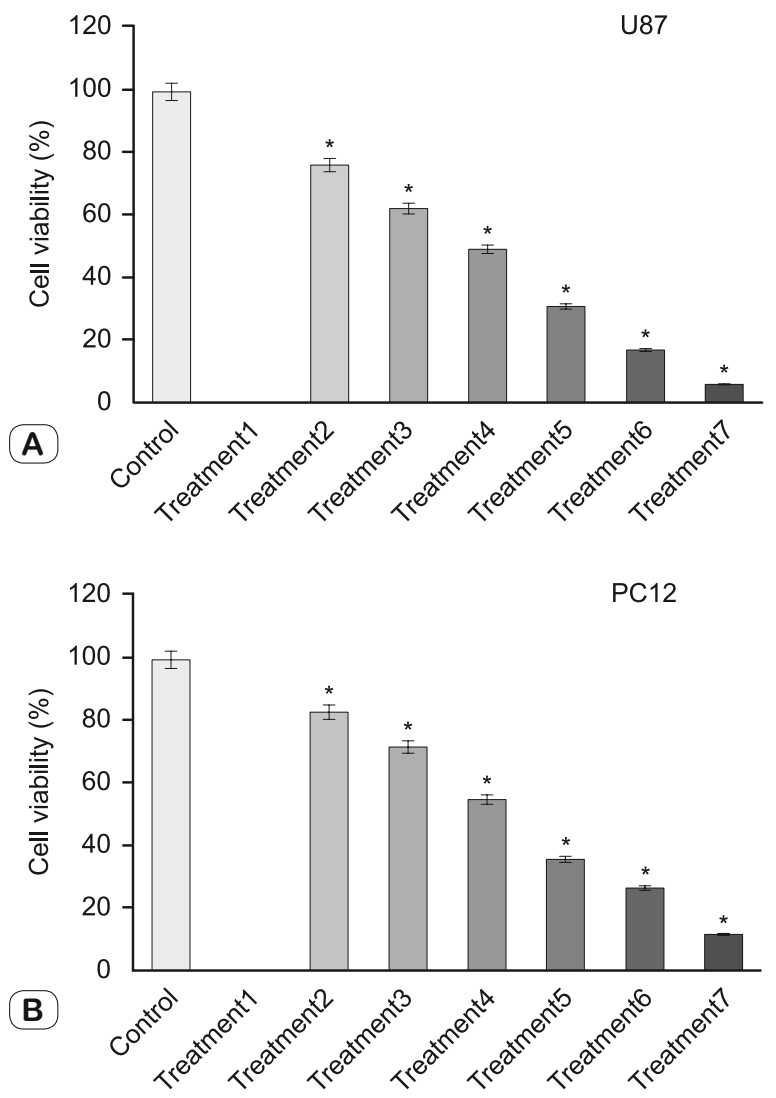

Fig. 1. The effects of different treatments on the cell viability of the U87 and PC12 cells. A: For U87. B: for PC12 cell cultures. All data represented by the mean \pm S.E.M $(p<0.05)$.

\section{Cell cytotoxicity measurement}

Cell cytotoxicity was quantified in this study by LDH Cytoxicity Detection Kit (Roche, Germany).

\section{Caspase-3 assay}

PC12 and U87 cells were cultured in the different treatment media condition. The caspase activity colorimetric assay kit (Biotechne) was used for the measurement of treated cells lysates caspase- 3 activity according to the manufacturer's protocol and using a plate reader.

\section{Detection of mitochondrial membrane potential (MMP)}

MMP was measured using the cell permeable cationic fluorescence probe rhodamine 123 , for quantitative analysis. In summary; PC12 and U87 cells $3 \times 10^{4}$ cells/well were cultured and treated in different treatment media. Next, the cells were washed with PBS and incubated by $1 \mu \mathrm{M}$ rhodamine 123 for $30 \mathrm{~min}$ at $37^{\circ} \mathrm{C}$ in the dark. Then, an ELISA Reader was used for measurement of cells absorbance at 488 excitation and $525 \mathrm{~nm}$ emission. The reference wavelength was more than $630 \mathrm{~nm}$. All the experiments were replicated independently at least three times. Within each experiment, we replicated each condition four times. 

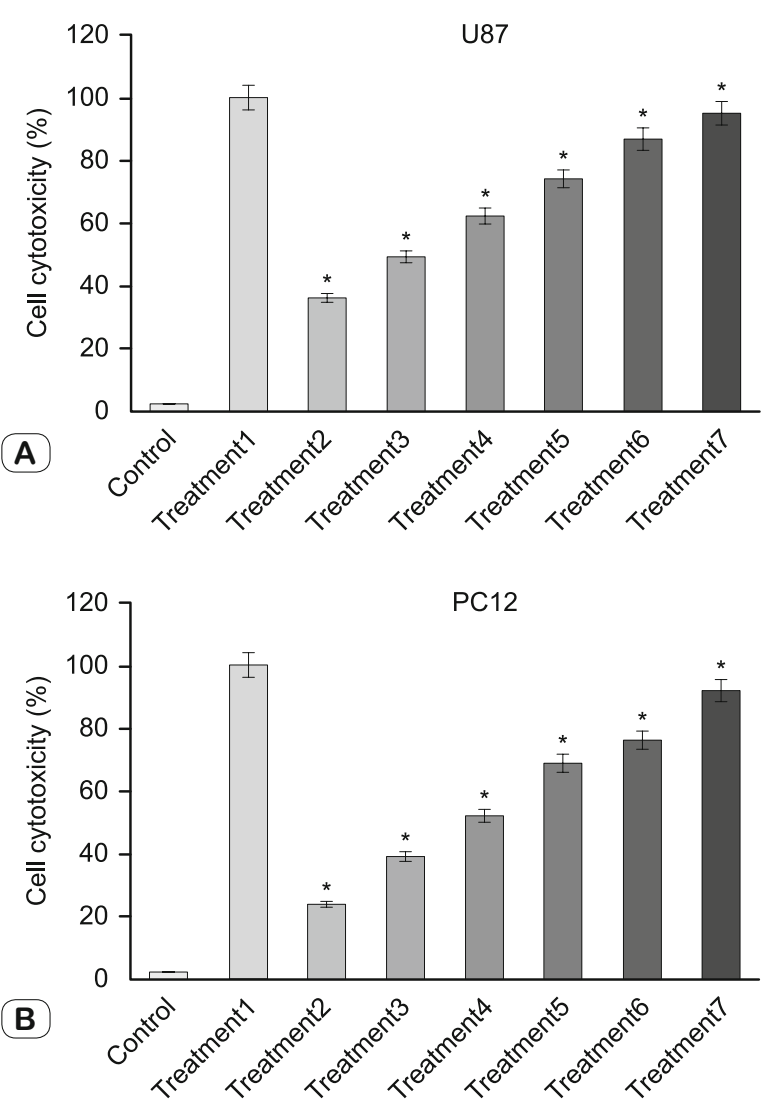

Fig. 2. The effects of different treatments on the cell cytotoxicity on U87 and PC12 cells. A: For U87. B: for PC12 cell cultures. All data represented by the mean \pm S.E.M $(p<0.05)$.

\section{Quantification of apoptosis incidence}

Fixation for all cells in this study was performed by $4 \%$ $\mathrm{w} / \mathrm{v}$ paraformaldehyde in $\mathrm{PBS}$ with $\mathrm{pH}=7.4$ for $10 \mathrm{~min}$ at room temperature. For identification of the apoptotic cells by TUNEL (Terminal Uridine deoxynucleotidyl transferase dUTP Nick End Labeling) staining, we used an in situ cell death detection kit (Roche), based on manufacturers protocol.

\section{Measurement of $\left(\mathrm{Ca}^{2+}\right)$ ic and $\left(\mathrm{Ca}^{2+}\right) \mathrm{m}$}

Measurement of intracellular $\left(\mathrm{Ca}^{2+}\right)$ ic and mitochondrial $\left(\mathrm{Ca}^{2+}\right)$ $\mathrm{m}$ calcium concentration was carried out on the base of previous studies (29).

$\left(\mathrm{Ca}^{2+}\right)$ ic values were calculated using the equation described by Grynkiewicz (30). Relative $\left(\mathrm{Ca}^{2+}\right) \mathrm{m}$ was measured with the fluorescent probe Rhod 2-AM following methods described previously (31).

\section{Measurement of antioxidant enzyme activities}

Antioxidant enzyme activities and protein damage assay were carried out on the base of previous studies (32). Briefly, in order to visualize intracellular ROS, cells were incubated with treatment media for $24 \mathrm{~h}$, and then washed three times with Krebs-Ringer-
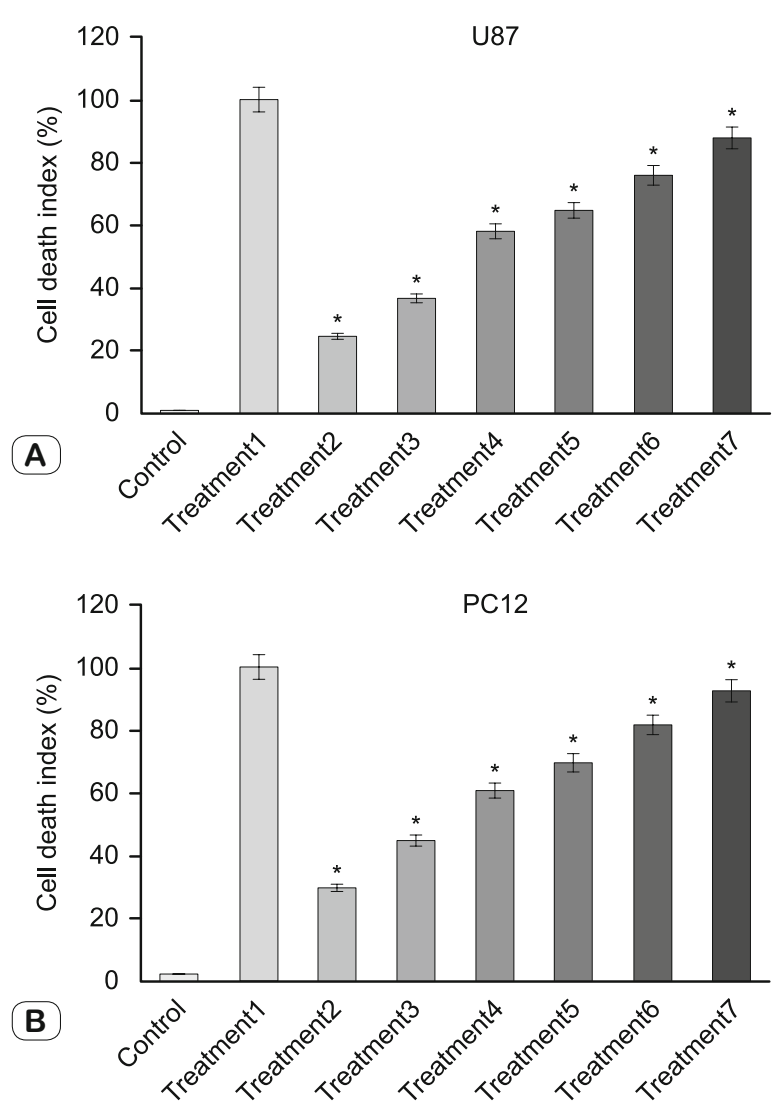

Fig. 3. The effects of different treatments on the cell death on U87 and PC12 cells. A: For U87. B: for PC12 cell cultures. All data represented by the mean \pm S.E.M $(p<0.05)$.

Hepes (KRH) buffer, and cells were incubated for $1 \mathrm{~h}$ at $37{ }^{\circ} \mathrm{C}$. Fluorescence (Ex. $490 \mathrm{~nm}$ and Em. $525 \mathrm{~nm}$ ) was visualized using a fluorescence microscope.

\section{Results}

\section{Cell culture}

Cell Viability (\%)

Different concentrations of morphine and constant methamphetamine concentration was added to the PC12 and U87 cell cultures, so, after $24 \mathrm{~h}$, MTT assay was used for the cell viability measurement. Control treatments showed $99 \%$ of cell viability as the result in both cell lines. In treatment $1,1 \mathrm{mM}$ of methamphetamine caused all the cells to die, so $0 \%$ of cell viability was clear in both treatments. Results showed that exposure of the cells to the 2-7 treatment media decreased the cell viability of these treatments compared to the control cells $(\mathrm{p}<0.05)$. The percentage of cell viability were increased in 2-7 treatments compared to the treatment 1 , respectively $(\mathrm{p}<0.05)$. The lowest and highest cell viability was for treatment $1(0 \%$ for both cell lines) and treatment 2 , respectively (Fig. 1$)(\mathrm{p}<0.05)$. 

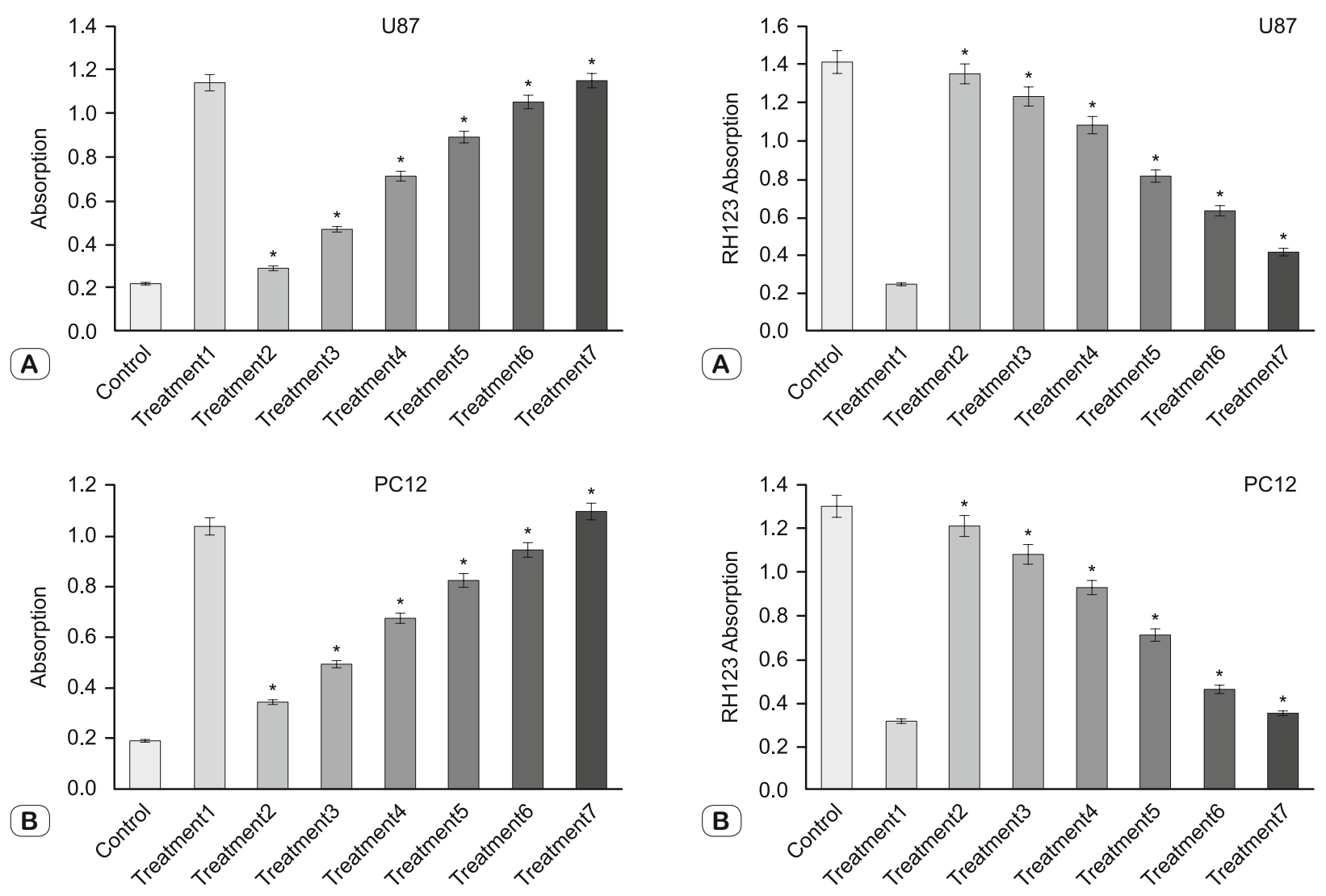

Fig. 4. The effects of different treatments on the caspase-3 activity on U87 and PC12 cells. A: For U87. B: for PC12 cell cultures. All data represented by the mean \pm S.E.M $(p<0.05)$.

\section{Cell cytotoxicity (\%)}

PC12 and U87 cells were exposed to different concentrations of morphine and constant concentration of methamphetamine (1 $\mathrm{Mm})$, so, after $24 \mathrm{~h}$, the cell cytotoxicity was measured by LDH assay. Control treatments, showed us $2 \%$ of cell cytotoxicity as the result in both cell lines. In treatment $1,1 \mathrm{mM}$ of methamphetamine caused all the cells to die, so the cytotoxicity $100 \%$ was clear in both treatments. The results showed that exposure of the cells to the 2-7 treatment media increased the cell cytotoxicity of these treatments compared to the control cells $(p<0.05)$. The percentage of cell cytotoxicity was decreased in $2-7$ treatments compared to treatments- 1 in both cell lines $(p<0.05)$. In both cell lines, the lowest cell cytotoxicity was in treatment 2 and the highest cell cytotoxicity was in treatment 1, respectively (Fig. 2) $(\mathrm{p}<0.05)$.

\section{Cell death index}

The cells were exposed to different concentrations of morphine and constant concentration of methamphetamine, so after 24 $\mathrm{h}$, cell death was measured by TUNEL assay. Control treatments showed us $1 \%$ of cell death as the result for PC12 and U87 cells.

Fig. 5. The effects of different treatments on the Mitochondrial membrane potential (Rhodamine-123 absorbance) on U87 and PC12 cells. A: For U87. B: for PC12 cell cultures. All data represented by the mean \pm S.E.M $(p<0.05)$.

In treatment 1 , all of the cells died because of methamphetamine and the percentage of cell death was $100 \%$. The results showed that exposure of the cells to $2-7$ treatment media caused cell death increases compared to the control cells, respectively $(\mathrm{p}<0.05)$. The percentage of cell death decreased in 2-7 treatments compared with treatments 1 , but as concentration increased the protective potential of morphine decreased $(\mathrm{p}<0.05)$. The results confirmed similarity in both cell lines (Fig. 3).

\section{Caspase-3 assay}

In most cases, apoptosis eventually mediates a common pathway through the result obtained in case of caspase- 3 activation. Furthermore, results showed that Caspase 3 activation after $24 \mathrm{~h}$ in treatments $2-7$ was increased compared to the control treatments $(\mathrm{p}<0.05)$. The caspase 3 activation in control treatments of PC12 and U87 cells was lower than in other treatments (treatments $1-7)(p<0.05)$. Caspase-3 activation in treatments $2-7$ were lower compared to the treatment 1 , as morphine concentration increased its protective potential decreased in both cell lines (Fig. 4) $(\mathrm{p}<0.05)$. 

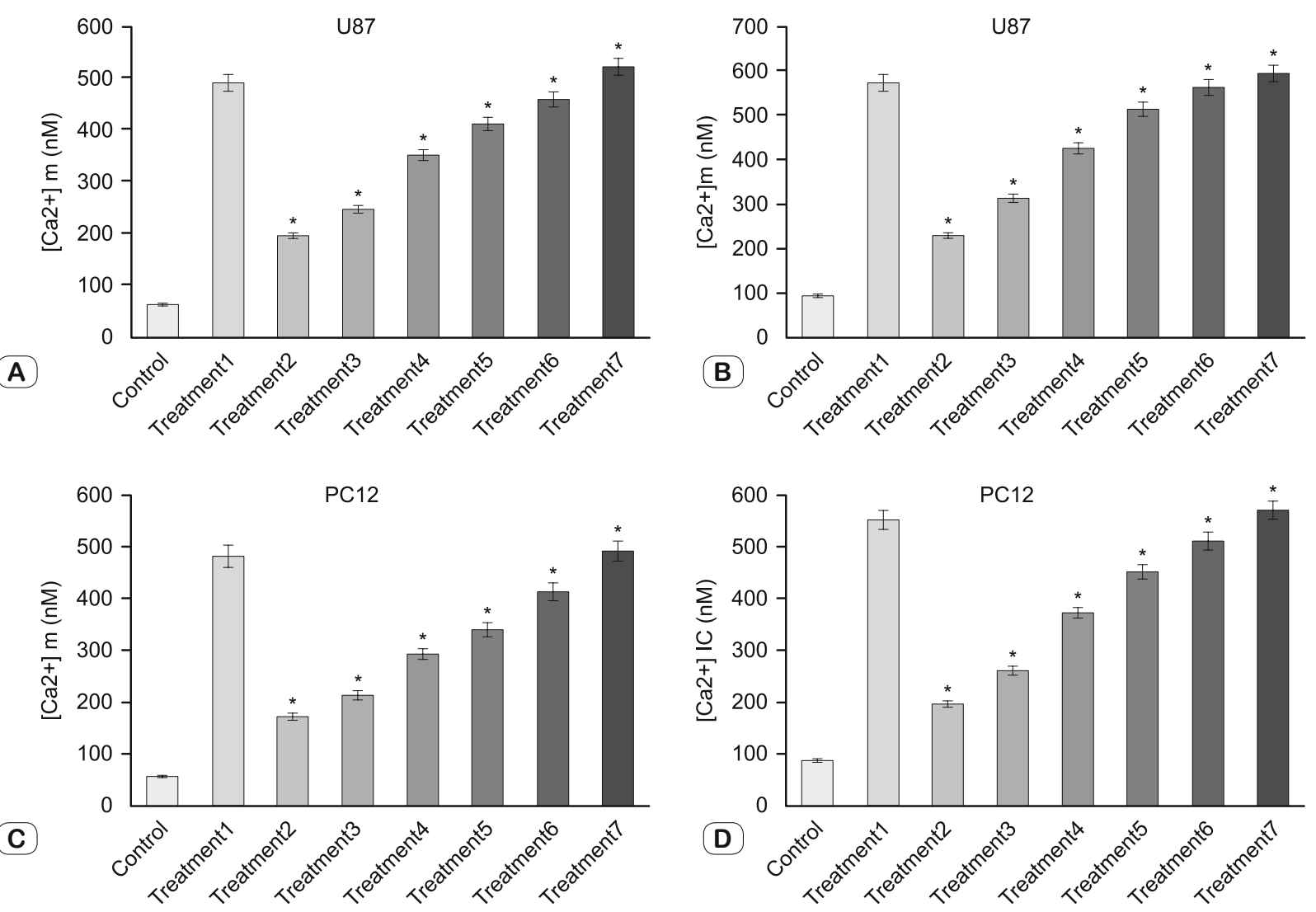

Fig. 6. Determination of $\left(\mathrm{Ca}^{2+}\right) \mathrm{m}$ and $\left(\mathrm{Ca}^{2+}\right)$ ic in different treated cells of $\mathrm{U} 87$ and PC12. A: $\left(\mathrm{Ca}^{2+}\right) \mathrm{m}$ of $\mathrm{U87}$ cells. B: $\left(\mathrm{Ca}^{2+}\right)$ ic of U87 cells. C: $\left(\mathrm{Ca}^{2+}\right) \mathrm{m}$ of PC12 cells. D: $\left(\mathrm{Ca}^{2+}\right)$ ic of PC12 cells. All data represented by the mean \pm S.E.M $(\mathrm{p}<0.05)$.

\section{Mitochondrial membrane potential (Rhodamine-123 absorbance)}

Through the apoptosis processes, in most cases caspase- 3 activation leads to mitochondrial membrane potential $(\Delta \varphi \mathrm{m})$ change, that eventually mediate a common pathway of cell death, which is named apoptosis.

To checking this $\Delta \varphi \mathrm{m}$ change in the treated cells, both cell lines were exposed to different treatment media, after $24 \mathrm{~h}, \Delta \varphi \mathrm{m}$ was measured by Rhodamine-123 staining and colorimetry assay.

Furthermore, RH-123 absorption in all treatments after $24 \mathrm{~h}$ was decreased compared to the control treatment in PC12 and U87 cells $(\mathrm{p}<0.05)$. The RH-123 absorption in control cells was higher than other treatments (treatments 1-7) $(\mathrm{p}<0.05)$. RH-123 absorption in treatments 2-7 were higher compared to treatment 1 , as morphine concentration increased its protective potential decreases $(\mathrm{p}<0.05)$. The results were similar for both cell types (Fig. 5).

\section{$\left(\mathrm{Ca}^{2+}\right)$ ic and $\left(\mathrm{Ca}^{2+}\right) \mathrm{m}$}

Exposure of $\mathrm{PC} 12$ and $\mathrm{U} 87$ cells to different media had specific and obvious effect on $\left(\mathrm{Ca}^{2+}\right)$ ic and $\left(\mathrm{Ca}^{2+}\right) \mathrm{m}$. In 2-7 treatments, the $\left(\mathrm{Ca}^{2+}\right)$ ic were increased in comparison with the control groups in both cell lines $(\mathrm{p}<0.05)$ (Fig. 6). It seems that $\mathrm{Ca}^{2+}$ might have accumulated in mitochondria, because morphine decreased con- centration of $\left(\mathrm{Ca}^{2+}\right)$ ic in 2-7 treatments. So, we evaluated changes in $\left(\mathrm{Ca}^{2+}\right) \mathrm{m}$ in cells loaded with the mitochondrial $\mathrm{Ca}^{2+}$ indicator by microscope. After comparison of the treatment inhibitors with treatment 1 , a significant decrease in $\left(\mathrm{Ca}^{2+}\right) \mathrm{m}$ was observed both in the PC12 and the U87 cells (Fig. 6).

\section{Measurement of antioxidant enzyme activities}

Results revealed that the exposure of PC12 and U87 cells to different treatment media had a clear effect on ROS (.OH) generation. The $(. \mathrm{OH})$ generation in treatments $2-7$ was increased compared to the control cells $(\mathrm{p}<0.05)$ and it was decreased in treatments $2-7$ compared to the treatment $1(\mathrm{p}<0.05)$. It was clear that overload of intracellular and mitochondrial $\mathrm{Ca}^{2+}$ caused enhanced accumulation and cytochrome c release in ROS pathway in treatment 1 cells, and this event was reverse in 2-7 treatments in compared to the treatment 1 . These observations occurred in both cell types (Fig. 7).

\section{Discussion}

The abuse of methamphetamine over the last few decades has become a major and growing global dilemma, like cocaine abuse 

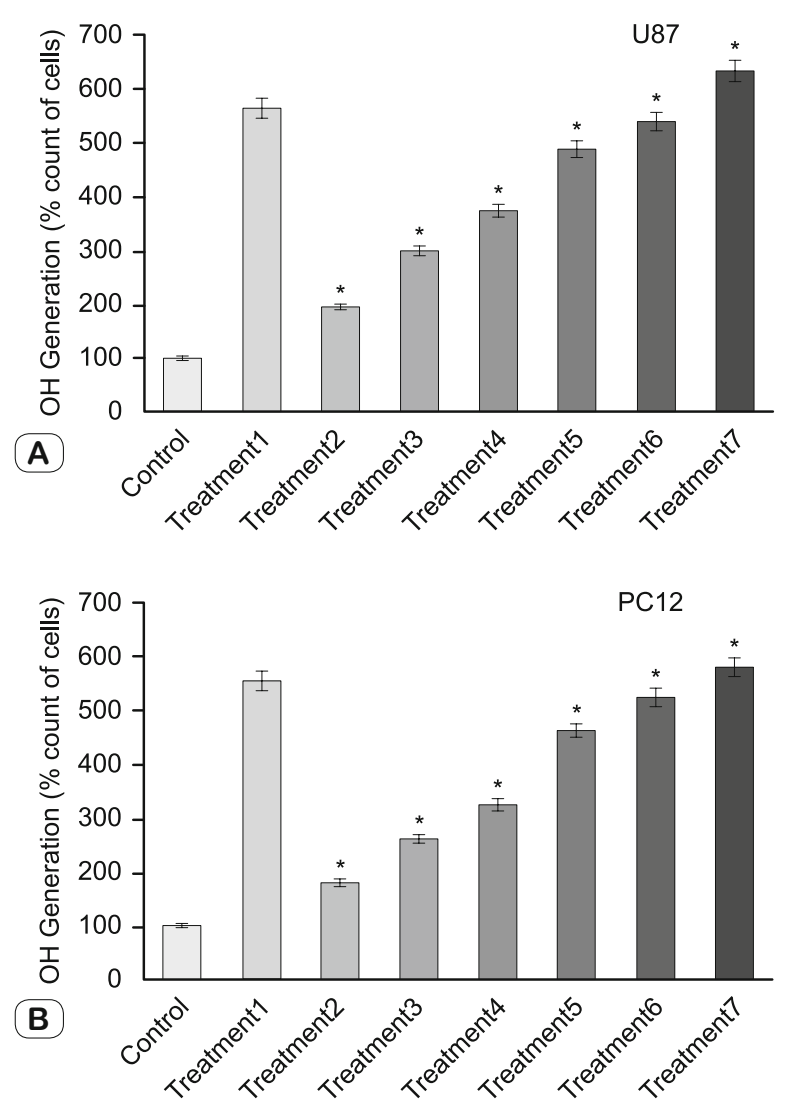

Fig. 7. The antioxidants and reduce agents of endogenous reactive oxygen species (ROS) production in treated cells of U87 and PC12. A: .OH generation in U87 cells. B: .OH Generation in PC12 cells. All data represented by the mean \pm S.E.M $(p<0.05)$.

$(33,34)$. This inexpensive drug is easily available and highly addictive, most commonly used in smoking form, but it can also be snorted, injected, swallowed, or inserted rectally $(8,35-38)$. Methamphetamine is often used by white men between 18-25 years old, native Hawaiians, hybrids, native Americans and homosexual men. In a 2002 survey, the addictive percentage between methamphetamine users was 10.6 up from approximately 22.3 in 2004 (8, 39-41). Methamphetamine use in low doses made extra satisfaction, attention, and strength in users but it has many side effects such as: myocardial infarction, concussion, annexation, rhabdomyolysis, and psychosis that may also lead to death (42-44).

Chronic methamphetamine use increases the risk of some highrisk viruses such as: hepatitis $\mathrm{C}$ and HIV and is associated with neurologic and psychiatric symptoms. Most of the deaths due to methamphetamine abuse are associated with high-risk emotional behaviors such as: suicide and accidents caused by dangerous driving (45-47).

Necrosis, apoptosis, and autophagy are morphological types of cell death $(27,28)$. Apoptosis is known as processes that lead to condensation of chromatin, fragmentation of cell nucleus and cell shrinkage, while cell death due to cellular swelling and mem- brane fracture is called necrosis. Methamphetamine induces apoptosis in dopaminergic and serotonergic neurons of mesencephalic and cortex cell culture. Also, in the PC12 cell line, derived from a pheochromocytoma in adrenal medulla of the rat, methamphetamine causes non-apoptotic cell death $(48,49)$.

Extra experiments showed that morphine can reduce tert-butyl hydroperoxide destructive effects on H9c2 cells (rat cardiomyoblast) and have positive effects on cell viability. Morphine can increase total antioxidant capacity of $\mathrm{H} 9 \mathrm{c} 2$ cells, can reduce the ROS production, protein carbonylation, and lipid peroxidation (19).

In this study, we tried to investigate the protective effects of morphine on cell cytotoxicity, low viability and apoptotic behaviors of PC12 and U87 cell lines culture treated by methamphetamine. It has been shown previously that methamphetamine increases the cell cytotoxicity and apoptosis and reduces cell viability of neuronal cell culture (50). The PC12 as a rat model and U87 as a human nerve cell line have been widely used to study the molecular mechanisms of neuronal cell death $(51,52)$. In this way, we have affected the different concentrations of morphine from $1 \mathrm{pM}$ to $100 \mu \mathrm{m}$ at a constant concentration of methamphetamine in $\mathrm{pc} 12$ cells to the achievement of best methamphetamine/morphine ratio to reduce the harmful effects of methamphetamine by concomitant use of methamphetamine and morphine. In both cell lines, morphine reduced cell cytotoxicity and increased cell viability in a dose-dependent manner, so that its optimum concentration was $1 \mathrm{pM}$. This indicates that morphine has the ability to reduce inflammation and apoptosis, especially at low concentrations. On the other hand, our results showed that morphine could reduce (.OH) production. In this experiment, the optimum concentration was also $1 \mathrm{pM}$. In low concentrations, morphine can reduce (.OH) production, which reduces the production of inflammatory cytokines such as: IL-1, IL-6, IL-10 and TNF $\alpha$, thus reducing inflammation, and therefore reducing apoptosis. Morphine at low concentrations increases the cAPM's concentration. This increase in concentration leads to the activation of the Erk $1 \& 4$ and the Erk $2 \& 3$ paths. These pathways are associated with the reduction of apoptosis. As the result, morphine reduces inflammation and increased differentiation, leading to a reduction in methamphetamine-induced cell death in PC12 and U87 cell lines in a dose-dependent manner. Our study showed that morphine can reduce intracellular and mitochondrial $\mathrm{Ca}^{2+}$. It prevents mitochondrial membrane destruction as the result, so the cytochrome $\mathrm{c}$ will not enter the cytosol as an apoptotic signal and will not activate the mitochondrial apoptotic pathway. Further, we used rhodamine 123 for monitoring of mitochondrial inner membrane electron potential as a marker of mitochondrial function. Afterwards, TUNNEL test was performed for DNA fragmentation detection. Our results, like previous results, showed that morphine in a dose-dependent manner, by $1 \mathrm{pM}$ optimal concentration, prevents disruption of the mitochondrial inner membrane and DNA fragmentation. The study of caspase 3 activity was consistent with previous information and argued that caspase 3 activity as an effector caspase in the pathway of apoptosis decreases in lower concentrations of morphine. As the result of this study, we can say that morphine has a maximum effect on the reduction of methamphetamine-induced cell death in the opti- 
mal concentration of $1 \mathrm{pM}$, which indicates the anti-inflammatory properties of morphine in the neural cells and the differentiation role of this substance in very low doses. On the other hand, as morphine concentration increases, its anti-inflammatory and antiapoptotic effects decrease, so that in higher concentrations it can reduce cAMP and increase inflammation and apoptosis.

\section{Conclusion}

Finally, we can say that low levels of morphine have anti-inflammatory, anti-apoptotic and neuroprotective properties. It can be therefore used to treat inflammatory and neurogenic diseases. It also reduces the effects of methamphetamine abuse. However, at high concentrations, the opposite and destructive effects of morphine are apparent.

\section{References}

1. Krasnova IN, Cadet JL. Methamphetamine toxicity and messengers of death. Brain Res Rev 2009; 60 (2): 379-407.

2. Farrell M, Marsden J, Ali R, Ling W. Methamphetamine: drug use and psychoses becomes a major public health issue in the Asia Pacific region. Addiction 2002; 97 (7): 771-772.

3. Rutkowski BA, Maxwell JC. Epidemiology of methamphetamine use. Methamphetamine Addiction: From Basic Science to Treatment Guilford Press, New York. 2009: 6-29.

4. Schifano F, Corkery J, Cuffolo G. Smokable (ice, crystal meth) and non smokable amphetamine-type stimulants: clinical pharmacological and epidemiological issues, with special reference to the UK. Annali dell'Istituto superiore di sanitÃ. 2007.

5. Volkow ND, Wang G-J, Fowler JS, Logan J, Gatley SJ, Wong C et al. Reinforcing effects of psychostimulants in humans are associated with increases in brain dopamine and occupancy of D2receptors. J Pharm Exp Ther 1999; 291 (1): 409-415.

6. Homer BD, Solomon TM, Moeller RW, Mascia A, DeRaleau L, Halkitis PN. Methamphetamine abuse and impairment of social functioning: a review of the underlying neurophysiological causes and behavioral implications. Psychol Bull 2008; 134 (2): 301.

7. Schepers RJ, Oyler JM, Joseph RE, Cone EJ, Moolchan ET, Huestis MA. Methamphetamine and amphetamine pharmacokinetics in oral fluid and plasma after controlled oral methamphetamine administration to human volunteers. Clin Chem 2003; 49 (1): 121-132.

8. Winslow BT, Voorhees KI, Pehl KA. Methamphetamine abuse. Amer Fam Phys 2007; 76 (8).

9. Thompson PM, Hayashi KM, Simon SL, Geaga JA, Hong MS, Sui Y et al. Structural abnormalities in the brains of human subjects who use methamphetamine. J Neurosci 2004; 24 (26): 6028-6036.

10. Ernst T, Chang L, Leonido-Yee M, Speck O. Evidence for long-term neurotoxicity associated with methamphetamine abuse A 1H MRS study. Neurology 2000; 54 (6): 1344-1349.

11. Cadet JL, Jayanthi S, Deng X. Methamphetamine-induced neuronal apoptosis involves the activation of multiple death pathways. Review. Neurotoxicity Res 2005; 8 (3-4): 199-206.

12. Nestler EJ. Molecular basis of long-term plasticity underlying addiction. Nat Rev Neurosci 2001; 2 (2): 119.
13. Thomas DM, Francescutti-Verbeem DM, Liu X, Kuhn DM. Identification of differentially regulated transcripts in mouse striatum following methamphetamine treatment-an oligonucleotide microarray approach. J Neurochem 2004; 88 (2): 380-393.

14. Cadet JL, Jayanthi S, Mccoy MT, Vawter M, Ladenheim B. Temporal profiling of methamphetamine-induced changes in gene expression in the mouse brain: evidence from cDNA array. Synapse 2001; 41 (1): 40-48.

15. Stefanis L. Caspase-dependent and-independent neuronal death: two distinct pathways to neuronal injury. Neuroscientist. 2005; 11 (1): 50-62.

16. Deng X, Jayanthi S, Ladenheim B, Krasnova IN, Cadet JL. Mice with partial deficiency of c-Jun show attenuation of methamphetamineinduced neuronal apoptosis. Mol Pharmacol 2002; 62 (5): 993-1000.

17. Jayanthi S, Deng X, Ladenheim B, McCoy MT, Cluster A, Cai N et al. Calcineurin/NFAT-induced up-regulation of the Fas ligand/Fas death pathway is involved in methamphetamine-induced neuronal apoptosis. Proc Nat Acad Sci 2005; 102 (3): 868-783.

18. Callahan BT, Cord BJ, Yuan J, McCann UD, Ricaurte GA. Inhibitors of $\mathrm{Na}+/ \mathrm{H}+$ and $\mathrm{Na}+/ \mathrm{Ca} 2+$ exchange potentiate methamphetamineinduced dopamine neurotoxicity: possible role of ionic dysregulation in methamphetamine neurotoxicity. J Neurochem 2001; 77 (5): 1348-1362.

19. Skrabalova J, Karlovska I, Hejnova L, Novotny J. Protective Effect of Morphine Against the Oxidant-Induced Injury in H9c2 Cells. Cardiovasc Toxicol 2018; 18 (4): 374-385.

20. Flemming K. The use of morphine to treat cancer-related pain: a synthesis of quantitative and qualitative research. J Pain Symptom Manag 2010; 39 (1): 139-154.

21. Cao LH, Li HT, Lin WQ, Tan HY, Xie L, Zhong ZJ et al. Morphine, a potential antagonist of cisplatin cytotoxicity, inhibits cisplatin-induced apoptosis and suppression of tumor growth in nasopharyngeal carcinoma xenografts. Sci Rep 2016; 6: 18706.

22. Gross ER, Hsu AK, Gross GJ. Opioid-induced cardioprotection occurs via glycogen synthase kinase $\beta$ inhibition during reperfusion in intact rat hearts. Circulat Res 2004; 94 (7): 960-966.

23. Gross ER, Hsu AK, Gross GJ. The JAK/STAT pathway is essential for opioid-induced cardioprotection: JAK2 as a mediator of STAT3, Akt, and GSK-3ß. Amer J Physiol Heart Circ Physiol 2006; 291 (2): H827-H834.

24. Xi J, Tian W, Zhang L, Jin Y, Xu Z. Morphine prevents the mitochondrial permeability transition pore opening through $\mathrm{NO} / \mathrm{cGMP} / \mathrm{PKG} /$ Zn2+/GSK-3 $\beta$ signal pathway in cardiomyocytes. Amer J Physiol Heart Circ Physiol 2009; 298 (2): H601-H607.

25. Gülçın I, Beydemır Ş, Alici HA, Elmastaş M, Büyükokuroğlu ME. In vitro antioxidant properties of morphine. Pharmacol Res 2004; 49 (1): $59-66$.

26. Clark MJ, Homer N, O'Connor BD, Chen Z, Eskin A, Lee H et al. Correction: U87MG Decoded: The Genomic Sequence of a Cytogenetically Aberrant Human Cancer Cell Line. PLoS Genet 2018; 14 (5): e1007392.

27. Kerr JF, Wyllie AH, Currie AR. Apoptosis: a basic biological phenomenon with wideranging implications in tissue kinetics. Brit J Cancer 1972; 26 (4): 239.

28. Uemura K, Aki T, Yamaguchi K, Yoshida K-i. Protein kinase C- $\varepsilon$ protects $\mathrm{PC} 12$ cells against methamphetamine-induced death: possible involvement of suppression of glutamate receptor. Life Sci 2003; 72 (14): 1595-1607. 
29. Seo SR, Seo JT. Calcium overload is essential for the acceleration of staurosporine-induced cell death following neuronal differentiation in PC12 cells. Exp Mol Med 2009; 41 (4): 269.

30. Grynkiewicz G, Poenie M, Tsien RY. A new generation of $\mathrm{Ca} 2+$ indicators with greatly improved fluorescence properties. J Biol Chem 1985; 260 (6): 3440-3450.

31. Hoth M, Fanger CM, Lewis RS. Mitochondrial regulation of storeoperated calcium signaling in T lymphocytes. J Cell Biol 1997; 137 (3): 633-648.

32. Abe S, Ohnishi H, Tsuchiya K, Ishizawa K, Torii M, Kanematsu Y et al. Calcium and reactive oxygen species mediated $\mathrm{Zn} 2+$-induced apoptosis in PC12 cells. J Pharmacol Sci 2006; 102 (1): 103-111.

33. Dong N, Zhu J, Han W, Wang S, Yan Z, Ma D et al. Maternal methamphetamine exposure causes cognitive impairment and alteration of neurodevelopment-related genes in adult offspring mice. Neuropharmacol 2018; 140: 25-34.

34. Ashok AH, Mizuno Y, Volkow ND, Howes OD. Association of stimulant use with dopaminergic alterations in users of cocaine, amphetamine, or methamphetamine: a systematic review and meta-analysis. JAMA Psychiatry 2017 ; 74 (5): 511-519.

35. Rafnar BO, Bjarnadottir GD. Intravenous Abuse of Methylphenidate. The SAGE Handbook of Drug \& Alcohol Studies: Biological Approaches. 2016: 401.

36. Connors NJ, Hoffman RS. Amphetamines and Derivatives. Crit Care Toxicol 2016; 1-26.

37. Richards JR, Brofeldt BT. Patterns of tooth wear associated with methamphetamine use. J Periodontol 2000; 71 (8): 1371-1374.

38. Rothman RB, Baumann MH, Dersch CM, Romero DV, Rice KC, Carroll FI et al. Amphetamine-type central nervous system stimulants release norepinephrine more potently than they release dopamine and serotonin. Synapse 2001; 39 (1): 32-41.

39. Colfax G, Vittinghoff E, Husnik MJ, McKirnan D, Buchbinder S, Koblin B et al. Substance use and sexual risk: a participant-and episodelevel analysis among a cohort of men who have sex with men. Amer J Epidemiol 2004; 159 (10): 1002-1012.

40. Shoptaw S, Reback CJ, Freese TE. Patient characteristics, HIV serostatus, and risk behaviors among gay and bisexual males seeking treatment for methamphetamine abuse and dependence in Los Angeles. J Addict Dis 2001; 21 (1): 91-105.

41. Negus S, Mello N, Blough B, Baumann M, Rothman R. Monoamine releasers with varying selectivity for dopamine/norepinephrine versus serotonin release as candidate "agonist" medications for cocaine dependence: studies in assays of cocaine discrimination and cocaine selfadministration in rhesus monkeys. J Pharmacol Exp Ther 2007; 320 (2): 627-636.

42. Silber BY, Croft RJ, Papafotiou K, Stough C. The acute effects of d-amphetamine and methamphetamine on attention and psychomotor performance. Psychopharmacology 2006; 187 (2): 154-169.

43. Mooney ME, Herin DV, Schmitz JM, Moukaddam N, Green CE, Grabowski J. Effects of oral methamphetamine on cocaine use: a randomized, double-blind, placebo-controlled trial. Drug Alcohol Depend 2009; 101 (1-2): 34-41.

44. Shariatirad S, Maarefvand M, Ekhtiari H. Methamphetamine use and methadone maintenance treatment: an emerging problem in the drug addiction treatment network in Iran. Internat J Drug Policy 2013; 24 (6): e115-e116.

45. Taylor MJ, Letendre SL, Schweinsburg BC, Alhassoon OM, Brown GG, Gongvatana A et al. Hepatitis C virus infection is associated with reduced white matter $\mathrm{N}$-acetylaspartate in abstinent methamphetamine users. J Internat Neuropsychol Society 2004; 10 (1): 110-113.

46. Kesby JP, Heaton RK, Young JW, Umlauf A, Woods SP, Letendre SL et al. Methamphetamine exposure combined with HIV-1 disease or gp120 expression: comparison of learning and executive functions in humans and mice. Neuropsychopharmacol 2015; 40 (8): 1899.

47. Herbeck DM, Brecht M-L, Lovinger K. Mortality, causes of death, and health status among methamphetamine users. J Addict Dis 2015; 34 (1): $88-100$.

48. Kim S, Westphalen R, Callahan B, Hatzidimitriou G, Yuan J, Ricaurte GA. Toward development of an in vitro model of methamphetamine-induced dopamine nerve terminal toxicity. J Pharmacol Exp Ther 2000; 293 (2): 625-633.

49. Simantov R, Tauber M. The abused drug MDMA (Ecstasy) induces programmed death of human serotonergic cells. FASEB J 1997; 11 (2): 141-146.

50. Xiong K, Liao H, Long L, Ding Y, Huang J, Yan J. Necroptosis contributes to methamphetamine-induced cytotoxicity in rat cortical neurons. Toxicol in vitro 2016; 35: 163-168.

51. San Tang K. Protective effect of arachidonic acid and linoleic acid on 1-methyl-4-phenylpyridinium-induced toxicity in PC12 cells. Lipids Health Dis 2014; 13 (1): 197.

52. Kang SS, Ahn EH, Zhang Z, Liu X, Manfredsson FP, Sandoval IM et al. $\alpha$-Synuclein stimulation of monoamine oxidase-B and legumain protease mediates the pathology of Parkinson's disease. EMBO J 2018: e201798878. 